\title{
Ondřej Podavka, Zdeněk Brtnický z Valdštejna. Učený šlechtic a jeho deník z cest, Vyšehrad, Praha 2017, ss. 28o (Lukáš M. Vytlačil)
}

Zdeněk Brtnický z Valdštejna, poslední představitel této valdštejnské rodové větve, patřil mezi př́slušníky bohaté moravské aristokracie a zároveň mezi velice vzdělané muže své doby. $O$ to překvapivější však možná je, jak málo prostoru se mu dostalo v současné historiografii. Tuto mezeru se pokouší zaplnit monografie Ondřeje Podavky, která vyšla jako 25. svazek ediční řady „Velké postavy českých dějin“. Nejde o první autorovu práci k osobnosti Zdeňka Brtnického, nebot již dřive k tomuto tématu napsal několik studií ${ }^{1}$ a disertační práci obhájenou v roce 2017.

Autor upozorňuje hned v úvodu knihy na nedostatek pramenů, přičemž také charakterizuje ty nejvýznamnější, podle nichž zároveň zásadním způsobem utvářel výslednou podobu knihy. Těmi jsou Brtnického latinský deník (Diarium), jejž si vedl především v době svých studií a kavalírské cesty, a dále památník (Stammbuch). Oba zachycují jen část jeho života, nejlépe pak léta 1596-1600, kdy si je Valdštejn vedl současně. Jinak se však nedochovalo mnoho biografických údajů, což Podavku vedlo ke zvolení poměrně netypické struktury. Životopisnou povahu má pouze několik prvních a posledních kapitol, mezi nimiž je v několika tematických celcích rozbor cestovního deníku.

Zdeněk Brtnický se narodil patrně 12. května 1582, ale okolo data panují nejasnosti. Jejich vysvětlováním se však autor nezabývá a odkazuje čtenáře na jinou svoji studii (s. 21). Přitom právě vědecká monografie je ideálním prostorem pro kom-

1 O. Podavka, Památník Zdeňka Brtnického $z$ Valdštejna $z$ let 1591-1600, Folia Historica Bohemica 29 (2014), č. 1, s. 103-132. Dále tentýž: Formování náboženského presvědčení Zdeñka Brtnického z Valdštejna a Ladislava Velena ze Žerotína, Studia Comeniana et historica. Časopis Muzea J. A. Komenského v Uherském Brodě pro komeniologii, historii 16.-18. století a regionální dějepis moravsko-slovenského pomezí 46 (2016), č. 95-96. 
plexní pojednání, ne-li dokonce př́mo očekávaným. Při popisu rodinných předků zaujme skutečnost, že členové rodu patřili mezi vzdělané muže své doby (s. 12). Několik z nich studovalo na univerzitě ve Wittenbergu a vychovatelem Zdeňkova strýce Hynka Brtnického byl Petr Codicillus, význačný humanista z pražské university. Po časné smrti Zdeňkova otce Jindřicha Brtnického byl právě Hynek jedním z jeho poručníků a svého synovce také učinil dědicem, čímž později došlo ke spojení všech panství Brtnických z Valdštejna (Brtnice, Sádek a Moravské Budějovice) v jedněch rukou. Zároveň však mladý šlechtic během dětství a dospívání ztratil téměř celou svoji rodinu a nejblíže mu byla babička Alena Berková z Dubé, rozená Meziř́ččská z Lomnice, z poručníků pak Smil Osovský z Doubravice, byt mezi nimi později došlo k jistým sporům při předávání dědictví. Další pasáže jsou věnovány vzdělání. Vedle míst a škol Podavka zmiňuje samozřejmě také osobnosti, které Brtnického formovaly. Jeho preceptorem byl po celou dobu Adam Ropal z Ryfmberka, ale měl možnost navazovat bližší kontakty i s celou řadou dalších osobností jak na domácí Moravě, tak i během pobytu ve Slezsku. Asi nejvýznamnějším byl Matyáš Borbonius z Borbenheimu.

Mnoho dalších příležitostí pak nabídla kavalírská cesta, kterou Zdeněk Brtnický podnikl v letech 1599 až 1602 a vedla přes Štrasburk do Francie, obou částí Nizozemí, Anglie, Švýcarska a Itálie. Přiložená mapa cesty na s. 33 bohužel není nijak podrobná a přehledná, cestovní itinerář je však shrnut alespoň v jejím popisu, bohužel však jen ve formě názvů obcí bez dat. Právě k této cestě poskytují výše zmíněné prameny celou řadu zpráv, byt' se jejich četnost i informační obsažnost $v$ čase proměňují, stejně jako zájmy urozeného cestovatele. Zde před námi vyrůstá obraz všestranně humanisticky vzdělaného aristokrata ovládajícího několik jazyků, živě se zajímajícího o celou řadu oborů a navazujícího osobní kontakty s předními učenci své doby.

Samotný popis kavalírské cesty Podavka dělí do šesti tematicky vymezených kapitol. V nich se zabývá Valdštejnovými studii, intelektuálními zájmy, městským prostředím a krajinou, každodenností na cestách, navazovanými společenskými kontakty a vazbami, nakonec též vztahem $k$ náboženství. Takto vytěžená zjištění autor srovnává s dalšími známými cestami i dobovými reáliemi. Velké úsilí bylo věnováno rovněž identifikaci navštívených míst, jejichž jména a názvy český cestovatel zapisoval tak, jak jim byl schopen porozumět. Cenné jednotlivosti bohužel nevyvažují skutečnost, že separací jednotlivých informací se zásadně ztrácí celkový a komplexní obraz cesty, jak ji Brtnický absolvoval a jak také vypovídá o jeho životě v tomto období. Klade to značné nároky na pamět čtenáře, který je nucen k neustálé komparaci mezi kapitolami, protože jedině tak se z knihy dozví alespoň trochu komplexně, čemu 
všemu věnoval Brtnický pozornost a čas na konkrétních místech a jak se jeho zájmy a pozornost během několikaleté cesty proměňovaly napříc rámcem stanovených témat. Ani to však nenahradí popis cesty v takové plnosti, jakou lze od biografické knihy očekávat tím spíše, že Podavkovo dílo vyšlo v ediční řadě životopisů významných českých osobností. Tento způsob výkladu s sebou vedle fragmentárnosti nese také poměrně časté duplikování informací, nebot je logicky třeba některé informace opakovat. Bez celkového kontextu deníku též není možné řadu věcí z pozice čtenáře/uživatele posoudit a podobné je to i s některými prezentovanými výklady autora. Př́ikladem může být třeba hudba (s. 72-73). Je dosti sporné, že by označení hudebního zvuku za krásný bylo samo o sobě projevem Valdštejnovy schopnosti ocenit (a tedy posoudit) hudební kvalitu, stejně jako jeho zájem o varhany mohl být veden třeba i jejich technickou či výtvarně-uměleckou hodnotou. Rovněž málo zmínek o koncertech, na které autor knihy upozorňuje, může být dáno vcelku prozaickými důvody. Veřejné koncerty se totiž $v$ té době ještě neporádaly a vedle panovnických a šlechtických ${ }^{2}$ dvorů se hudba hrála nejčastěji v kostelích při bohoslužbách. A jak sám Podavka uvádí jinde, těch se v katolických zemích Brtnický jako evangelík patrně moc neúčastnil.

Značné limity tohoto př́stupu vnímám také v otázce konfese, na kterou čtenář více či méně latentně naráží v podstatě již od prvních stránek o rodině a vzdělání, aby explicitně řečené odpovědi našel až v kapitole od strany 190. Přitom problematika latinských škol, stejně jako minimálně část významných společenských i politických vazeb mezi šlechtou s otázkou náboženské orientace úzce souvisí. Podavka zde jinak přináší prrínosné informace a na jejich základě Brtnického identifikuje jako luterána filipistického směru, který u nás nebyl př́liš rozšířen.

Následně se kniha vrací k biografickému výkladu a zabývá se Valdštejnovým životem po návratu do českých zemí. Jak dokládá dochovaná korespondence, kontakty mladého aristokrata byly v zásadě definovány prostorem západní Moravy, v němž se pohyboval také Smil Osovský z Doubravice, stejně jako kontakty Karla staršího ze Žerotína, předáka moravských nekatolických stavỉ, jenž rovněž patřil mezi velmi blízké podporovatele mladého brtnického pána. $Z$ okruhu evangelické šlechty pocházely též obě jeho manželky: Magdaléna z Thurnu a Kateřina Křinecká z Ronova.

$\mathrm{V}$ další kapitole se čtenár seznamuje s hospodařením Valdštejna coby brtnické vrchnosti. Zde Podavka upozorňuje na pozoruhodnou skutečnost. I přes svůj původ

2 Zde je však třeba připomenout, že fenomén zámeckých či šlechtických kapel se naplno rozvinul až v baroku. 
a pozemkový majetek fakticky až do stavovského povstání nevystupoval v domácí politice a nevykonával ani žádnou ze zemských funkcí, což se změnilo až s připojením Moravy k povstání a nástupem Fridricha Falckého, k jehož dvořanům Valdštejn patřil. Vliv mohla mít jednak jeho konfesní profilace, která samozřejmě v době vyostřujícího se konfliktu s katolíky kolem císařského dvora nebyla výhodou, ale zřejmě také dluhy, které musel řešit po návratu z cest. I přes zajímavé ekonomické detaily, jež zde autor knihy uvádí, není popis tak úplný, jak by mohl být a jak umožňují dostupné prameny. Zcela schází např́klad důležitý popis tehdejších valdštejnských panství a čtenář se tedy o rozsahu pozemkových majetků brtnických Valdštejnů nic nedozví. Je sice pravda, že z doby správy Zdeňka Brtnického se mnoho pramenů nedochovalo, ale např. pro brtnické panství jsou urbářové informace z doby jeho předchůdcư ${ }^{3}$, stejně jako konfiskační odhad ze 17. listopadu $1622^{4}$. Tento konfiskační dokument byl vytvořen po Valdštejnově uvěznění na brněnském Špilberku, kde také kvůli špatným podmínkám a patrně dlouhodobě nedobrému zdravotnímu stavu zemřel.

Jistým zklamáním jsou také poměrně omezené obrazové př́lohy. $\mathrm{V}$ barvě zde nacházíme jen dobové veduty ze spisu Civitates orbis terrarum, ukázky z Valdštejnova památníku jsou pouze černobílé. Další vyobrazení ilustrují většinou současnou podobu míst navštívených při kavalírské cestě. Z domácích sídel brtnických Valdštejnů je v knize zařazena pouze jediná fotografie zámku v Brtnici, ale Sádek či bývalý luteránský kostel v Brtnici, v němž také Hynek Brtnický zř́dil rodovou hrobku, již nikoliv.

Z mnoha aspektů knihy je patrná výrazná orientace autora na zpracování Valdštejnova deníku a jeho další interpretaci. Náročně vytvořené tematické celky by měly smysl spíše jako analytický doplněk cestopisu, který by byl hlavní částí publikace (třeba v podobě latinského originálu se souběžným překladem). Bez celkového deníkového líčení však uvedené informace ztrácejí svůj kontext a pro uživatele životopisné publikace tedy nutně i část výpovědní hodnoty. Edici deníku ostatně autor avizuje jako svůj budoucí zájem. Namísto radosti z vydání odborného životopisu opomíjené osobnosti Zdeňka Brtnického z Valdštejna tedy převládají spíše rozpaky.

3 J. Janák a kol., Dèjiny Brtnice, Brno-Třebíč 1988, s. 112-115.

4 Tamtéž, s. 124-125. 